\title{
Present and Future Non-Surgical Therapeutic Strategies for the Management of Periodontal Diseases
}

\author{
Renata S. Leite ${ }^{1,3}$ and Keith L. Kirkwood 2,3 \\ 1 Department of Stomatology and \\ ${ }^{2}$ Craniofacial Biology, College of Dental Medicine, \\ ${ }^{3}$ Center for Oral Health Research, Medical University of South Carolina, \\ Charleston, SC, \\ USA
}

\section{Introduction}

Periodontal disease is a chronic bacterial infection of the periodontium affecting the tissues surrounding and supporting the teeth. Periodontal disease progression is associated with subgingival bacterial colonization and biofilm formation principal to chronic inflammation of soft tissues, degradation of collagen fibers supporting the tooth to the gingiva and alveolar bone, as well as resorption of the alveolar bone itself. Since the fundamental role of microorganisms in its etiology was systematically demonstrated some forty years ago, research efforts have long focused on identifying the pathogenic microorganisms and their virulence factors (Socransky and Haffajee, 1994). The search for these putative microorganisms was driven, in part, by knowledge indicating that colonization of the oral cavity and presence of dental biofilm is normally associated with health, similarly to the colonization of the colon. To treat periodontal diseases as an infectious disease, numerous therapeutic strategies aimed at eradication of periodontal pathogens have been studied over the years, including local and systemic delivery of antimicrobial and antibiotic agents. This review will cover an update on chemotherapeutic agents used adjunctively to treat and manage periodontal diseases.

In the current paradigm of periodontal disease, specific periodontal pathogens are necessary for disease initiation; however, the extent and severity of tissue destruction are largely dependent on the nature of the host-microbial interactions. These interactions are dynamic, since both the microbial composition of the dental biofilm and the competency of host immune responses can vary, in the same individual, over time. This concept was developed in parallel to the advances on the understanding of the immune response, and research on periodontal disease has been emphasizing mechanisms of host-microbial interactions to understand the disease process, as well as for the development of novel therapeutic strategies. For the past two decades, the host response to the bacterial challenge originating from the dental biofilm has been considered to play a major role on both initiation of the disease and on the tissue destruction associated with its progress (Kirkwood, et al., 2007). The importance of host-microbial interactions is reinforced by epidemiological data indicating different susceptibilities to periodontal disease among individuals, in spite of the 
long-term presence of oral biofilm (Baelum and Fejerskov, 1986, Baelum, et al., 1988, Loe, et al., 1986). Other studies demonstrating increased susceptibility and greater severity of periodontal disease in individuals with impaired immune response due to systemic conditions also indicate the significance of the host response to the bacterial challenge (Feller and Lemmer, 2008, Mealey, 1998). Both past and future directions of host-modulatory agents will be addressed here to provide the dental practitioner with a broader prospective of chemotherapeutic agents used to manage periodontal diseases.

\section{Antibiotics}

Contemporary periodontal therapies aim at mechanical removal of bacterial deposits to maintain a healthy sulcus or produce an environment suitable for new attachment. The inability of mechanical treatment to produce a desirable root surface in all cases coupled with the nature and complexity of the subgingival biofilm has fueled the search for adjunctive treatment regimens that increase the likelihood to successfully manage periodontal diseases.

While more than 700 bacterial species may be present in the gingival sulcus, it is clear that only a subset of bacterial species are consistently found to be associated with diseased sites. These findings make the prospect of targeted antibiotic therapy an attractive goal. The literature on antimicrobial periodontal therapy has been thoroughly reviewed (Ellen and McCulloch, 1996, Goodson, 1994, van Winkelhoff, et al., 1996).

\subsection{Systemic antibiotics}

Adjunctive systemic antibiotic therapies have indicated beneficial effects for patients with periodontal diseases., The optimal timing of antimicrobial drug administration is still a subject of discussion, as the literature is controversial whether it should be administered during the initial non-surgical phase (Loesche, et al., 1992), or during a subsequent surgical phase (Herrera, et al., 2008). Although not directly confirmed yet by a clinical trial, it seems preferable, from a general health point of view, to let patients benefit early from the positive systemic effects of successful periodontal therapy. Table 1 provides an overview of some orally active systemic antibiotics commonly used in clinical periodontics.

Caution should be noted that none of these antibiotics is to be used as a monotherapy to treat periodontal diseases. Systemic antibiotics reach the periodontal tissues by transudation from the serum then cross the crevicular and junctional epithelia to enter the gingival sulcus. The concentration of the antibiotic in this site may be inadequate for the desired antimicrobial effect without mechanical disruption of the plaque biofilm. In addition to any effect produced in the sulcus, a systemically administered antibiotic will produce antimicrobial effects in other areas of the oral cavity. This additional effect will reduce bacterial counts on the tongue and other mucosal surfaces, thus potentially aiding to delay re-colonization of subgingival sites. Research however, indicates that antibiotics are detectable in the sulcus and the range of their concentrations in the gingival crevicular fluid is known to be in therapeutic range treatment efficacy. Table 2 provides information to facilitate the clinician's decision to the most reasonable choice of antibiotic, dose and duration of administration.

Many studies have been completed and published describing the effect of systemic antibiotic therapy on periodontal disease. Several different treatment regimens have been employed successfully to manage periodontal diseases (Slots and Ting, 2002). Considering a number of studies, it can be stated generally that systemic antibiotic therapy has little effect 
on supragingival plaque accumulation with a possible exception in one study where doxycycline significantly decreased plaque accumulation at a twelve-week evaluation compared to placebo ( $\mathrm{Ng}$ and Bissada, 1998).

\begin{tabular}{|c|c|c|c|c|}
\hline $\begin{array}{l}\text { Antibiotic } \\
\text { Class }\end{array}$ & Agent & Effect & $\begin{array}{c}\text { Target } \\
\text { Organisms }\end{array}$ & Limitation \\
\hline \multirow[t]{2}{*}{ Penicillin } & Amoxicillin & Bacteriocidal & $\begin{array}{l}\text { Gram + and } \\
\text { Gram - }\end{array}$ & $\begin{array}{l}\text { Penicillinase sensitive } \\
\text { Patient } \\
\text { hypersensitivity }\end{array}$ \\
\hline & Augmentin & Bacteriocidal & $\begin{array}{l}\text { Narrower } \\
\text { spectrum } \\
\text { than } \\
\text { Amoxicillin }\end{array}$ & $\begin{array}{l}\text { More expensive than } \\
\text { Amoxicillin }\end{array}$ \\
\hline \multirow[t]{3}{*}{ Tetracycline } & Tetracycline & Bacteriostatic & $\begin{array}{l}\text { Gram + > } \\
\text { Gram - }\end{array}$ & Bacterial resistance \\
\hline & Minocycline & Bacteriostatic & $\begin{array}{l}\text { Gram + > } \\
\text { Gram - }\end{array}$ & \\
\hline & Doxycycline & Bacteriostatic & $\begin{array}{l}\text { Gram + > } \\
\text { Gram - }\end{array}$ & \\
\hline Quinolone & Ciprofloxacin & Bacteriocidal & Gram - rods & Nausea, GI discomfort \\
\hline Macrolide & Azithromycin & $\begin{array}{l}\text { Bacteriostatic } \\
\text { OR } \\
\text { Bacteriocidal } \\
\text { depending on } \\
\text { concentration }\end{array}$ & & \\
\hline Lincomycin & Clindamycin & Bacteriocidal & $\begin{array}{l}\text { Anaerobic } \\
\text { bacteria }\end{array}$ & \\
\hline Nitroimidazole & Metronidazole & $\begin{array}{l}\text { Bacteriocidal } \\
\text { to Gram - }\end{array}$ & $\begin{array}{l}\text { Gram -; esp. } \\
P . \text { gingivalis } \\
\text { and } \\
P . \text { intermedia }\end{array}$ & $\begin{array}{l}\text { Not good choice for } A \text {. } \\
\text { Actinomycetemcomitans } \\
\text { infections }\end{array}$ \\
\hline
\end{tabular}

Table 1. Systemic antibiotic choices.

\begin{tabular}{|l|l|l|}
\hline \multicolumn{1}{|c|}{ Single Agent } & \multicolumn{1}{|c|}{ Regimen } & \multicolumn{1}{c|}{ Dosage/Duration } \\
\hline Amoxicillin & $500 \mathrm{mg}$ & Three times per day X 8 days \\
\hline Azithromycin & $500 \mathrm{mg}$ & Once daily X 4-7 days \\
\hline Ciprofloxacin & $500 \mathrm{mg}$ & Twice daily X 8 days \\
\hline Clindamycin & $300 \mathrm{mg}$ & Three times daily X 10 days \\
\hline Doxycycline or Minocycline & $100-200 \mathrm{mg}$ & Once daily X 21 days \\
\hline Metronidazole & $500 \mathrm{mg}$ & Three times daily X 8 days \\
\hline & & \\
\hline Combination Therapy & & \\
\hline Metronidazole + Amoxicillin & $250 \mathrm{mg}$ of each & Three times daily X 8 days \\
\hline Metronidazole + Ciprofloxacin & $500 \mathrm{mg}$ of each & Twice daily X 8 days \\
\hline
\end{tabular}

Table 2. Systemic antibiotic dosing regimens. 
Except for the combination of metronidazole with amoxicillin, systemic antibiotic treatment produces no clinically significant effects on periodontal pocket depth reduction compared with controls (Winkel, et al., 2001) ((Cionca, et al., 2009). A seven-day regimen of systemic metronidazole significantly reduced the percentage of sites with bleeding compared to controls (Watts, et al., 1986). Others have reported a 12-month reduction in bleeding after treatment with a metronidazole-amoxicillin combination compared to a placebo treatment (Lopez, et al., 2000). With respect to clinical attachment levels, systemic metronidazole and combinations of metronidazole with other antibiotics has shown improvement in several studies. Several investigators found significant improvement of attachment levels at sites initially 4-6 mm in depth with a seven-day treatment with metronidazole (Elter, et al., 1997, Loesche, et al., 1992, Loesche, et al., 1984). Winkel et al. showed that the combination of metronidazole and amoxicillin for 7 to 14 days produced a significant increase in the percentage of sites showing improved attachment levels compared to control sites (Winkel, et al., 2001). A combination of metronidazole and clindamycin for three weeks also produced improved attachment levels. (Gomi, et al., 2007, Sigusch, et al., 2001).

Some data to date supports a clinical benefit from the use of azithromycin as a systemic approach in combination with mechanical routines. In one limited study, seventeen subjects receiving azithromycin $(500 \mathrm{mg})$, three days before full-mouth scaling and root planing produced greater clinical improvement than in seventeen subjects treated with full-mouth scaling and root planing alone (Gomi, et al., 2007). Dastoor et al. studied thirty patients who reported smoking more than one pack per day and presented with periodontitis. A comparison was made between the response to treatment with periodontal surgery and 500 mg Azithromycin per day for three days and treatment with periodontal surgery only. The addition of Azithromycin did not enhance improvements seen in both groups for attachment gain, depth reduction and reduction of bleeding on probing. However, the adjunctive use of Azithromycin was associated with a lower gingival index at two weeks and what the authors saw as more rapid wound healing. The addition of Azithromycin also produced reductions of red-complex bacteria that were maintained to three months (Dastoor, et al., 2007).

It is important to remember that the systemic antibiotic therapy is not intended as a monotherapy but is always best as an adjunctive therapy combined with traditional mechanical therapy and patient plaque control.

\subsection{Local antibiotic therapy}

After considering the risk to benefit ratio of systemic antibiotic administration as an adjunct treatment of periodontal diseases, interest in antibiotic therapy applied locally was developed. Historically, the first such local antibiotic therapy for periodontal disease was the Actisite $^{\mathrm{TM}}$ (no longer commercially available) fiber system. Actisite ${ }^{\mathrm{TM}}$ was supplied as hollow, nonabsorbable fibers filled with tetracycline $(12.7 \mathrm{mg} / 9$ inch fiber). The fiber was inserted into the pocket, wrapped repeatedly circumferentially around the tooth keeping the fiber in the pocket. Often a periodontal dressing was placed to aid maintaining the fiber in the pocket. The fiber was retained for ten days until operator removal. During this ten-day period drug concentrations of more than $1300 \mu \mathrm{g} / \mathrm{ml}$ of tetracycline were achieved and maintained. When the fiber was removed the soft tissue was often distended allowing temporary improved access and visibility of the root surfaces for any additional root planing or calculus removal. Following removal of the fiber the soft tissues generally showed 
shrinkage and pocket reduction and reduction of the inflammatory response were commonly seen. The Actisite ${ }^{\mathrm{TM}}$ system, while very effective, was tedious to use and required the second visit for removal of the fiber. These issues fueled the development of an absorbable system (Table 3).

\begin{tabular}{|c|c|c|c|c|c|}
\hline $\begin{array}{c}\text { Antimicrobial } \\
\text { Agent }\end{array}$ & $\begin{array}{l}\text { Delivery } \\
\text { Form }\end{array}$ & Drawback & $\begin{array}{c}\text { GCF } \\
\text { Concentration }\end{array}$ & $\begin{array}{c}\text { Time to } \\
\text { Absorption }\end{array}$ & Brand Name \\
\hline $\begin{array}{l}\text { Tetracycline } \\
12.7 \text { mg per } 9 \\
\text { inches of fiber }\end{array}$ & Hollow fibers & $\begin{array}{l}2^{\text {nd }} \text { procedure } \\
\text { for fiber } \\
\text { removal }\end{array}$ & $\begin{array}{l}>1300 \mathrm{ug} / \mathrm{ml} \\
\text { for } 10 \text { days }\end{array}$ & $\begin{array}{l}\text { Not } \\
\text { absorbable }\end{array}$ & $\begin{array}{l}\text { Actisite } \\
\text { No longer } \\
\text { commercially } \\
\text { available } \\
\end{array}$ \\
\hline $\begin{array}{l}10 \% \\
\text { Doxycycline }\end{array}$ & $\begin{array}{l}\text { Fluid; multi- } \\
\text { site } \\
\text { depending on } \\
\text { volume of } \\
\text { site; in } \\
\text { syringe }\end{array}$ & $\begin{array}{l}\text { Often pulls } \\
\text { out when } \\
\text { removing } \\
\text { syringe }\end{array}$ & $\begin{array}{l}250 \mathrm{ug} / \mathrm{ml} \text { still } \\
\text { noted at } 7 \\
\text { days }\end{array}$ & 21 days & Atridox \\
\hline $\begin{array}{l}25 \% \\
\text { Metronidazole } \\
\text { Gel }\end{array}$ & $\begin{array}{l}\text { Fluid; } \\
\text { multi-site } \\
\text { depending on } \\
\text { volume of site; } \\
\text { in syringe }\end{array}$ & $\begin{array}{l}\text { May require } \\
\text { multiple } \\
\text { applications } \\
\text { for desirable } \\
\text { results }\end{array}$ & $\begin{array}{l}\text { More than } 120 \\
\mathrm{mg} / \mathrm{ml} \text { of } \\
\text { sulcus fluid in } \\
\text { the first few } \\
\text { hours }\end{array}$ & $\begin{array}{l}\text { Concentration } \\
\text { decreases } \\
\text { rapidly after } \\
\text { the first few } \\
\text { hours (Knoll- } \\
\text { Kohler, 1999) } \\
\end{array}$ & Elyzol \\
\hline $\begin{array}{l}2 \% \\
\text { Minocycline } \\
\text { Spheres }\end{array}$ & $\begin{array}{l}\text { Solid; in unit } \\
\text { doses applied } \\
\text { with syringe }\end{array}$ & $\begin{array}{l}\text { Unit doses } \\
\text { may not be } \\
\text { sufficient for } \\
\text { every site } \\
\text { volume } \\
\end{array}$ & $\begin{array}{l}\text { Therapeutic } \\
\text { drug levels for } \\
14 \text { days }\end{array}$ & 14 days & Arestin \\
\hline
\end{tabular}

Table 3. Local antibiotic delivery systems.

The first resorbable local antibiotic system was Atridox ${ }^{\mathrm{TM}}$ (Atrix Laboratories). In this system, longer half-lived doxycycline replaced tetracycline supplied at a concentration of $42.5 \mathrm{mg}$ per unit of material. Atridox ${ }^{\mathrm{TM}}$ improved the local antibiotic routines by allowing placement of the material to the depth of most pockets and in a manner that allowed it to conform to the shape of the pocket unlike the solid fibers of Actisite ${ }^{\mathrm{TM}}$. Depending on the size of the pocket, more than one site could be treated with a single unit of Atridox ${ }^{\mathrm{TM}}$.

Further development of absorbable local antibiotic systems led to Arestin ${ }^{\mathrm{TM}}$ (OraPharma) that uses minocycline in a microsphere configuration, each sphere measuring 20-60 microns in diameter. The antibiotic maintains therapeutic drug levels and remains in the pocket for 14 days. This configuration of the material allows placement to the depths of most pockets and while the material cannot conform to the shape of the pocket as well as the Atridox ${ }^{\mathrm{TM}}$ gel it is still better than the solid Actisite ${ }^{\mathrm{TM}}$ fibers.

Another material, not available in the United States, is Elyzol ${ }^{\mathrm{TM}}($ Colgate), a metronidazole gel system. This material is supplied as $25 \%$ metronidazole in a glyceryl mono-oleate and sesame oil base. The concentration of Metronidazole in this system is $250 \mathrm{mg} / \mathrm{g}$ of material that is applied as a gel using a syringe method. 
Overall efficacy of local antibiotic therapies has been evaluated using meta-analysis of fifty articles, each reporting studies of at least six months follow-up (Bonito, et al., 2005). The meta-analysis considered studies of the addition of local adjuncts and found such additions provide generally favorable but minimal differences. The clinical effects of these various systems have been reported in several publications. Table 4 summarizes several studies of various local adjunctive materials. The overall treatment effect is somewhat variable and while found to be statistically significant has led many to be suspect of the general clinical benefit.

\begin{tabular}{|l|c|c|c|l|}
\hline \multicolumn{1}{|c|}{ Agent } & Subjects & $\begin{array}{c}\text { Depth } \\
\text { Change } \\
\text { with S/RP } \\
\text { Only }\end{array}$ & $\begin{array}{c}\text { Depth } \\
\text { Change } \\
\text { with S/RP + } \\
\text { Agent }\end{array}$ & $\begin{array}{c}\text { Sites With At Least 2 mm } \\
\text { Attachment Gain with S/RP + } \\
\text { Agent }\end{array}$ \\
\hline $\begin{array}{l}\text { Tetracycline Fibers } \\
\text { (Goodson, et al., 1991) }\end{array}$ & 107 & 0.67 & $\begin{array}{c}1.02 \\
\text { (fiber only) }\end{array}$ & Not reported \\
\hline $\begin{array}{l}\text { Doxycycline gel } \\
\text { (Garrett, et al., 1999) }\end{array}$ & 411 & 1.08 & $\begin{array}{c}1.30 \\
\text { (drug only) }\end{array}$ & $38 \%$ (drug only) \\
\hline $\begin{array}{l}\text { Doxycycline gel } \\
\text { (Wennstrom, et al., } \\
\text { 2001) }\end{array}$ & 105 & 1.3 & 1.5 & $52 \%$ \\
\hline $\begin{array}{l}\text { Doxycycline gel } \\
\text { (Machion, et al., 2006) }\end{array}$ & 48 & $1.5-2.19$ & $1.63-2.29$ & $34.4 \%$ vs. 18.1\% S/RP only \\
\hline $\begin{array}{l}\text { Minocycline spheres } \\
\text { (Williams, et al., 2001) }\end{array}$ & 728 & 1.08 & 1.32 & $42 \%$ \\
\hline $\begin{array}{l}\text { Minocycline spheres } \\
\text { (Goodson, et al., 2007) }\end{array}$ & 127 & 1.01 & 1.38 & $\begin{array}{l}\text { Not reported; reports attachment } \\
\text { gain of } 1.16 \text { with agent, 0.8 S/RP } \\
\text { only }\end{array}$ \\
\hline $\begin{array}{l}\text { Metronidazole gel } \\
\text { (Ainamo, et al., 1992) }\end{array}$ & 206 & 1.3 & $\begin{array}{c}1.5 \\
\text { (drug only) }\end{array}$ & Not reported \\
\hline $\begin{array}{l}\text { Azithromycin gel } \\
\text { (Pradeep, et al., 2008) }\end{array}$ & 80 & 2.13 & 2.53 & $\begin{array}{l}\text { Not reported; reports greater } \\
\text { gain at all time points with agent }\end{array}$ \\
\hline
\end{tabular}

Table 4. Local Antibiotic System Studies.

\section{Antiseptics}

The use of chemical agents with anti-plaque or anti-gingivitis action as adjuncts to oral hygiene seems to be of limited value, since mouthrinses do not appreciably penetrate into the gingival crevice, but they are of specific benefit when used as adjuncts to control gingival inflammation, especially in acute situations and during periods of interrupted hygiene (Ciancio, 1989). The challenge with chemical plaque control is to develop an active anti-plaque agent that does not disturb the natural flora of the oral cavity. The American Dental Association (ADA) Seal of Acceptance is seen as a standard for oral health care products. The ADA Seal Program ensures that professional and consumer dental products meet rigorous ADA criteria for safety and effectiveness. Guidelines have been established for the control of gingivitis and supragingival plaque 
(http://www.ada.org/ada/seal/index.asp). These guidelines describe the clinical, biological, and laboratory studies necessary to evaluate safety and effectiveness and are subject to revision at any time. Importantly, they do not describe criteria for evaluating the management of periodontitis or other periodontal diseases. All claims of efficacy, including all health benefit claims, (e.g. gingivitis reduction), and all claims which imply a health benefit (e.g. plaque reduction) must be documented. There will be two Seal statements to be used with an Accepted product, depending on whether or not the product's mechanism of action is related to plaque reduction.

Oral antiseptics have evolved from short-lived effects (soon after rinsing) as with the first generation antimicrobials (Table 5) to the second generation, which have the antimicrobial effect that lasts for a time period after the mouthrinse has been expectorated (Table 6).

\begin{tabular}{|c|c|c|c|c|c|c|}
\hline $\begin{array}{l}\text { Anti- } \\
\text { microbial }\end{array}$ & $\begin{array}{c}\text { Commercial } \\
\text { Name }\end{array}$ & $\begin{array}{l}\text { ADA Seal } \\
\text { of } \\
\text { Acceptance }\end{array}$ & $\begin{array}{c}\text { Active } \\
\text { ingredients }\end{array}$ & $\begin{array}{l}\text { Alcohol } \\
\text { content }\end{array}$ & $\begin{array}{c}\text { Mechanism of } \\
\text { Action }\end{array}$ & $\begin{array}{l}\text { Efficacy published } \\
\text { by the manufacturer }\end{array}$ \\
\hline $\begin{array}{l}\text { Phenolic } \\
\text { Compounds }\end{array}$ & $\begin{array}{l}\text { Listerine } \\
\text { (Johnson \& } \\
\text { Johnson) }\end{array}$ & Yes & $\begin{array}{l}\text { Essential } \\
\text { oils: } \\
\text { Thymol } \\
(0.06 \%) \\
\text { Eucalyptol } \\
(0.09 \%) \\
\text { Methyl } \\
\text { salicylate } \\
(0.06 \%) \\
\text { Menthol } \\
(0.04 \%) \\
\end{array}$ & $26.9 \%$ & $\begin{array}{l}\text { Appears to be } \\
\text { related to } \\
\text { alteration of the } \\
\text { bacterial cell } \\
\text { wall }\end{array}$ & $\begin{array}{l}52 \% \text { plaque } \\
\text { reduction } \\
36 \% \text { gingivitis } \\
\text { reduction } \\
(\text { www.listerine.com) }\end{array}$ \\
\hline Sanguinarine & $\begin{array}{l}\text { Viadent } \\
\text { (Colgate) }\end{array}$ & No & $\begin{array}{l}0.03 \% \\
\text { Sanguinarin } \\
\text { e extract }\end{array}$ & $5.5 \%$ & $\begin{array}{l}\text { Alteration of } \\
\text { bacterial cell } \\
\text { surfaces so that } \\
\text { aggregation and } \\
\text { attachment is } \\
\text { reduced }\end{array}$ & $\begin{array}{l}28 \% \text { plaque } \\
\text { reduction } \\
24 \% \text { gingivitis } \\
\text { reduction } \\
\text { (www.colgateprofes } \\
\text { sional.com/products } \\
\text { /Viadent-Advanced- } \\
\text { Care-Oral- } \\
\text { Rinse/details) } \\
\end{array}$ \\
\hline $\begin{array}{l}\text { Quaternary } \\
\text { Ammonium } \\
\text { Compounds }\end{array}$ & $\begin{array}{l}\text { Cepacol and } \\
\text { Scope } \\
\text { (Procter \& } \\
\text { Gamble) }\end{array}$ & No & $\begin{array}{l}\text { Cepacol: } \\
0.05 \% \text { CPC } \\
\text { Scope: } \\
0.045 \% \text { CPC } \\
+0.005 \% \\
\text { domiphen } \\
\text { bromide }\end{array}$ & $\begin{array}{l}\text { Cepacol } \\
14 \% \\
\text { Scope } \\
18.9 \%\end{array}$ & \begin{tabular}{|l|} 
Related to \\
increased \\
bacterial cell wall \\
permeability, \\
which favors \\
lysis, decreased \\
cell metabolism \\
and a decreased \\
ability for bacteria \\
to attach to tooth \\
surfaces.
\end{tabular} & $\begin{array}{l}15.8 \% \text { plaque } \\
\text { reduction } \\
15.4 \% \text { gingivitis } \\
\text { reduction } \\
\text { (www.cepacol.com/ } \\
\text { products/mouthwas } \\
\text { h.asp) and } \\
\text { (www.pg.com/prod } \\
\text { uct_card/prod_card } \\
\text { _main_scope.html) }\end{array}$ \\
\hline
\end{tabular}

Table 5. First generation antimicrobials. 
On the downside, it is also recognized that oral hygiene products may have the potential for producing harm in the mouth, some of which are more serious and long lasting than others. These types of harm range from production of a cosmetic nuisance, such as staining occurring as a result of the use of cationic antiseptics like chlorhexidine and cetylpyridinium chloride, to more permanent damage to the dental hard tissues through possible erosive and abrasive effects of low-pH mouthrinses and toothpastes respectively. Of serious concern is controversially the ability to produce carcinogenic changes to the oral mucosa through the use of alcoholic mouthrinses. Recently, the potential harm of oral hygiene products to oral and systemic health was fully reviewed with reference to present-day evidence (Addy, 2008).

\begin{tabular}{|l|l|l|}
\hline Antimicrobial & \multicolumn{1}{|c|}{$\begin{array}{c}\text { Cetylpyridinium } \\
\text { chloride }\end{array}$} & \multicolumn{1}{c|}{ Chlorhexidine } \\
\hline $\begin{array}{l}\text { Commercial } \\
\text { Name }\end{array}$ & $\begin{array}{l}\text { Crest Pro-Health } \\
\text { (Procter \& Gamble) }\end{array}$ & $\begin{array}{l}\text { Peridex (3M Espe) } \\
\text { Periogard (Colgate) }\end{array}$ \\
\hline $\begin{array}{l}\text { ADA Seal of } \\
\text { Acceptance }\end{array}$ & No & Yes \\
\hline $\begin{array}{l}\text { Active } \\
\text { ingredients }\end{array}$ & $0.07 \%$ CPC & $\begin{array}{l}\text { 0.12\% Chlorhexidine gluconate } \\
\text { (solutions.3m.com/wps/portal/3M/en_US/pr } \\
\text { eventive-care/home/products/home-care- } \\
\text { therapies/peridex/) and } \\
\text { (www.colgateprofessional.com/products/Colg } \\
\text { ate-Periogard-Rinse-Rx-only/details) }\end{array}$ \\
\hline $\begin{array}{l}\text { Mechanism of } \\
\text { Action }\end{array}$ & $\begin{array}{l}\text { Bactericidal agent } \\
\text { interacts with the bacterial } \\
\text { membrane. The cellular } \\
\text { pressure disrupts the cell } \\
\text { membrane and effectively } \\
\text { kills the bacteria. }\end{array}$ & $\begin{array}{l}\text { Positively charged chlorhexidine molecule } \\
\text { binds to negatively charged microbial cell wall, } \\
\text { altering osmotic equilibrium, causing potassium } \\
\text { and phosphorous leakage, precipitation of } \\
\text { cytoplasmic contents and consequent cell death. }\end{array}$ \\
\hline $\begin{array}{l}\text { Efficacy } \\
\text { published by } \\
\text { the } \\
\text { manufacturer }\end{array}$ & $\begin{array}{l}\text { Similar to Listerine } \\
\text { (www.dentalcare.com/so } \\
\text { ap/products/index.htm) }\end{array}$ & $\begin{array}{l}\text { Certain aerobic and anaerobic bacteria } \\
\text { reduction from 54 - 97\% through six months use } \\
\text { (solutions.3m.com/wps/portal/3M/en_US/pr } \\
\text { eventive-care/home/products/home-care- } \\
\text { therapies/peridex/) } \\
- \text { 29\% gingivitis reduction } \\
\text { - 54\% plaque reduction } \\
\text { (www.colgateprofessional.com/products/Colg } \\
\text { ate-Periogard-Rinse-Rx-only/details) }\end{array}$ \\
\hline
\end{tabular}

Table 6. Second generation antimicrobials.

\subsection{Phenolic compounds}

Among the first generation antimicrobials, the phenolic compounds, such as Listerine ${ }^{\circledR}$ and its clones, are the only ones that have the ADA Seal of Acceptance to prevent and reduce supragingival plaque accumulation and gingivitis. Short-term studies have shown plaque and gingivitis reduction averaging 35\% (Fornell, et al., 1975) and long-term studies have shown plaque reduction between 13.8 and $56.3 \%$ and gingivitis reduction between 14 and 
35.9\% (DePaola, et al., 1989, Gordon, et al., 1985). Possible adverse effects reported in the literature include a burning sensation, bitter taste and possible staining of teeth.

\subsection{Chlorhexidine}

Chlorhexidine gluconate $(0.12 \%)$, such as Peridex ${ }^{\circledR}$ and Periogard $\AA$, is sold in the United States by prescription only. It was the first antimicrobial shown to inhibit plaque formation and the development of chronic gingivitis (Loe and Schiott, 1970). Chlorhexidine is effective against gram-positive and negative bacteria and yeast. It has very low toxicity, since it is poorly absorbed from the GI tract and $90 \%$ is excreted in the feces. Chlorhexidine $0.12 \%$ is indicated for short-term (less than 2 months), intermittent short-term (alternating on and off every 1 to 2 months) and long-term (greater than 3 months to indefinitely) use (Table 7). Of all the products included here, chlorhexidine appears to be the most effective agent for reduction of both plaque and gingivitis with short-term reductions averaging $60 \%$ (Flotra, et al., 1972). Long-term reductions in plaque averaged between $45-61 \%$ and in gingivitis, $27-$ $67 \%$ (Ciancio, 1989). Adverse effects reported may include staining of teeth, reversible desquamation, poor taste and alteration of taste and an increase in supragingival calculus (Flotra, et al., 1972, Overholser, et al., 1990).

\begin{tabular}{|l|l|l|}
\hline $\begin{array}{c}\text { Short-term } \\
\text { indication } \\
\text { (less than 2 } \\
\text { months) }\end{array}$ & $\begin{array}{c}\text { Intermittent short-term } \\
\text { indications } \\
\text { (alternating on and off } \\
\text { every 1 to 2 months) }\end{array}$ & $\begin{array}{r}\text { Long-term indications } \\
\text { (greater then 3 months to indefinitely) }\end{array}$ \\
\hline Gingivitis & Gingivitis & $\begin{array}{l}\text { Patients with reduced resistance to } \\
\text { bacterial plaque: AIDS, leukemia, kidney } \\
\text { disease, bone marrow transplants, } \\
\text { agranulocytosis, thrombocytopenia }\end{array}$ \\
\hline $\begin{array}{l}\text { Following } \\
\text { periodontal and } \\
\text { oral surgery }\end{array}$ & Periodontal maintenance \\
\hline $\begin{array}{l}\text { During initial } \\
\text { periodontal } \\
\text { therapy }\end{array}$ & $\begin{array}{l}\text { Physically handicapped patients: } \\
\text { rheumatoid arthritis, scleroderma, } \\
\text { disturbance of muscles and/or motor } \\
\text { capacity and coordination }\end{array}$ \\
\hline $\begin{array}{l}\text { Treatment of } \\
\text { candidiasis }\end{array}$ & $\begin{array}{l}\text { Extensive prosthetic } \\
\text { reconstruction }\end{array}$ & $\begin{array}{l}\text { Patients treated with: cytotoxic drugs, } \\
\text { immunosuppressive drugs, and } \\
\text { radiation therapy. }\end{array}$ \\
\hline
\end{tabular}

Table 7. Chlorhexidine $0.12 \%$ Indications.

\subsection{Other antimicrobial mouthrinses}

Several other agents have been evaluated for their effect on bacterial plaque and gingivitis, but results are inferior to those of chlorhexidine and phenolic compounds (see Table 8). Pires et al. (Pires, et al., 2007) have concluded that a mouthwash containing a combination of Triclosan/Gatrez and sodium bicarbonate has an in-vitro antimicrobial activity superior to that of a placebo, but still inferior to that of chlorhexidine. 


\begin{tabular}{|c|c|c|c|c|c|}
\hline $\begin{array}{c}\text { Anti- } \\
\text { microbial }\end{array}$ & $\begin{array}{l}\text { Commercial } \\
\text { Name }\end{array}$ & $\begin{array}{c}\text { ADA } \\
\text { Seal of } \\
\text { Acceptance }\end{array}$ & $\begin{array}{c}\text { Active } \\
\text { ingredients }\end{array}$ & Mechanism of Action & Efficacy \\
\hline $\begin{array}{l}\text { Oxygenating } \\
\text { agents }\end{array}$ & $\begin{array}{l}\text { Peroxyl } \\
\text { (Colgate) }\end{array}$ & No & $\begin{array}{l}\text { Hydrogen } \\
\text { Peroxyde }\end{array}$ & $\begin{array}{l}\text { Anti-inflammatory } \\
\text { properties reduce bleeding } \\
\text { on probing, a major sign of } \\
\text { inflammation; bacterial load } \\
\text { is not necessarily reduced; } \\
\text { bubbling action cleans and } \\
\text { alleviates discomfort to } \\
\text { promote healing. }\end{array}$ & $\begin{array}{l}\text { Long-term studies do } \\
\text { not support } \\
\text { effectiveness. } \\
\text { Short-term studies } \\
\text { offer contradictory } \\
\text { findings. }\end{array}$ \\
\hline $\begin{array}{l}\text { Chlorine } \\
\text { Dioxide }\end{array}$ & $\begin{array}{l}\begin{array}{l}\text { RetarDEX } \\
\text { (Periproducts) }\end{array} \\
\text { Oxyfresh }\end{array}$ & No & $\begin{array}{l}1 \% \text { chlorine } \\
\text { dioxide }\end{array}$ & $\begin{array}{l}\text { Stable, free radical and an } \\
\text { oxidant with algicidal, } \\
\text { bactericidal, cysticidal, } \\
\text { fungicidal, sporicidal, and } \\
\text { viricidal properties. }\end{array}$ & $\begin{array}{l}\text { Minimal plaque } \\
\text { reduction, but has } \\
\text { shown decreases } \\
\text { involatile sulfur } \\
\text { compounds and } \\
\text { halitosis. }\end{array}$ \\
\hline \begin{tabular}{|l} 
Zinc \\
Chloride
\end{tabular} & Breath Rx & No & \begin{tabular}{|l|}
-Zinc \\
chloride \\
-Phenolic oils \\
(Thymol and \\
Eucalyptus \\
oil) \\
\end{tabular} & $\begin{array}{l}\text { Zinc has an affinity to } \\
\text { sulfur and odorizes } \\
\text { sulphydryl groups with } \\
\text { zinc ions forming stable } \\
\text { mercaptides with the } \\
\text { substrate, the precursors, } \\
\text { and/or the volatile sulfur } \\
\text { compounds directly. }\end{array}$ & $\begin{array}{l}\text { BreathRx is a } \\
\text { scientific bad breath } \\
\text { treatment specially } \\
\text { designed to help } \\
\text { treat both the causes } \\
\text { of bad breath and the } \\
\text { symptoms. }\end{array}$ \\
\hline Triclosan & $\begin{array}{l}\text { Not available } \\
\text { in the US }\end{array}$ & N/A & Triclosan & $\begin{array}{l}\text { A low toxicity, non-ionic } \\
\text { phenolic derivative with a } \\
\text { wide spectrum of } \\
\text { antimicrobial and anti- } \\
\text { inflammatory activities } \\
\text { (Kim, et al., 2005). }\end{array}$ & $\begin{array}{l}\text { In vitro studies show } \\
\text { antimicrobial activity } \\
\text { superior to that of a } \\
\text { placebo, but inferior to } \\
\text { that of chlorhexidine } \\
\text { (Pires, et al., 2007) }\end{array}$ \\
\hline
\end{tabular}

Table 8. Other antimicrobial mouthrinses.

\begin{tabular}{|l|l|l|l|}
\hline $\begin{array}{l}\text { Antiseptics } \\
\text { compared }\end{array}$ & \multicolumn{1}{|c|}{ Methodology } & \multicolumn{1}{|c|}{ Results } & \multicolumn{1}{|c|}{ References } \\
\hline $\begin{array}{l}\text { Listerine } \\
\text { Viadent } \\
\text { Peridex } \\
\text { Placebo }\end{array}$ & $\begin{array}{l}\text { 31 volunteers with healthy gingiva } \\
\text { ceased all oral hygiene procedures } \\
\text { but rinsing with the designated } \\
\text { mouthrinse for 21 days }\end{array}$ & $\begin{array}{l}\text { Peridex was superior in its } \\
\text { ability to maintain optimal } \\
\text { gingival health during the entire } \\
\text { time of mouthrinse use. }\end{array}$ & $\begin{array}{l}\text { Siegrist et al. } \\
\text { (Siegrist, et al., } \\
\text { 1986) }\end{array}$ \\
\hline $\begin{array}{l}\text { Listerine } \\
\text { Peridex } \\
\text { Placebo }\end{array}$ & $\begin{array}{l}\text { Double blind, controlled clinical } \\
\text { trial. After a baseline complete } \\
\text { dental prophylaxis,124 healthy } \\
\text { adults used the mouthrinse as a } \\
\text { supplement to regular oral hygiene } \\
\text { for 6 months. }\end{array}$ & $\begin{array}{l}\text { Both Listerine and Peridex } \\
\text { significantly inhibited } \\
\text { development of plaque by 36.1\% } \\
\text { and 50.3\%, respectively, and the } \\
\text { development of gingivitis by } \\
\text { 35.9\% and 3.0.5\% respectively, } \\
\text { compared to placebo. }\end{array}$ & $\begin{array}{l}\text { Overholser et al. } \\
\text { (Overholser, et } \\
\text { al., 1990) }\end{array}$ \\
\hline $\begin{array}{l}\text { Chlorhexidine } \\
\text { 0.12\% } \\
\text { Hydrogen } \\
\text { Peroxide 1\% } \\
\text { Placebo }\end{array}$ & $\begin{array}{l}\text { 32 subjects ceased oral hygiene } \\
\text { procedures, but rinsed, twice a day } \\
\text { with the designated mouthrinse for } \\
\text { 21 days. }\end{array}$ & $\begin{array}{l}\text { The chlorhexidine group showed } \\
\begin{array}{l}\text { 25\% reduction in gingivitis } \\
\text { incidence, 100\% reduction in BOP, } \\
\text { and 80\% reduction in plaque } \\
\text { scores compared to placebo. }\end{array}\end{array}$ & $\begin{array}{l}\text { Gusberti et al. } \\
\text { (Gusberti, et al., } \\
\text { 1988) }\end{array}$ \\
\hline
\end{tabular}

Table 9. Comparison studies. 


\section{Anti-inflammatory strategies}

It is well established that periodontal disease is an infectious disease and that the host immune and inflammatory response to the microbial challenge mediates tissue destruction (Offenbacher, 1996). Considering that the primary etiology of the disease are bacteria in the plaque and their products, mechanical and chemical approaches to reduce the presence of periodontopathogens in the plaque have been largely used in the treatment of periodontal patients over the years (Greenwell, 2001). Most recently, the better understanding of the participation of host immune-inflammatory mediators in the disease progression has increased the investigation of the use of modulating agents as an adjunctive therapy to the periodontal treatment. Inhibition or blockade of proteolytic enzymes, pro-inflammatory mediators and of osteoclast activity has been the focus of these agents which has lead to encouraging results in pre-clinical and clinical studies (Reddy, et al., 2003). More specifically, three types of host-modulatory agents have been investigated for the management of periodontitis including anti-proteinases (MMP inhibitors), antiinflammatory agents, and anti-resorptive agents.

\subsection{MMP Inhibitors}

One important group of proteolytic enzymes present in the periodontal tissues is formed by the matrix metalloproteinases (MMPs), which include collagenases, gelatinases and metalloelastases. MMPs are produced by many periodontal tissues and are responsible for remodeling the extracellular matrix (Birkedal-Hansen, 1993). In 1985, tetracyclines were found to have anti-collagenolytic activity and proposed as a host modulating agent for periodontal treatment (Golub, et al., 1985). Initial studies demonstrated that doxycycline was the most potent tetracycline in inhibition of collagenolytic activities (Burns, et al., 1989). This property of doxycycline provided the pharmacological rationale for the use of a low or subantimicrobial dose of doxycycline (SDD) that was shown to be efficient in inhibiting mammalian collagenase activity without developing antibiotic resistance (Golub, et al., 1990).

Several clinical studies have been conducted assessing the benefits of the SDD as an adjunctive therapy to scaling and root planing (SRP) in the treatment of the periodontal disease. Reddy et al. recently presented a meta-analysis (Reddy, et al., 2003) of 6 selected clinical studies comparing long-term systemic SDD (20mg bid doxycycline) to placebo control in periodontal patients. A statistically significant adjunctive benefit on clinical attachment levels (CAL) and probing depth was found when SDD was used in combination with SRP, in both 4 to $6 \mathrm{~mm}$ and $\geq 7 \mathrm{~mm}$ pocket depth categories. Bleeding on probing (BOP) was not assessed in the meta-analysis but, in general, SDD did not improve this parameter when compared to placebo. No significant adverse effects were reported in any of the studies.

\subsection{Non-steroid anti-inflammatory drugs}

The non-steroidal anti-inflammatory drugs (NSAIDs) represent the next major pharmacological class of agents that has been well studied as inhibitors of the host response in periodontal disease. These agents are well known for the ability to prevent prostanoid formation. In this process, arachidonic acid liberated from membrane phospholipids of cells after tissue damage or stimulus is metabolically transformed via cyclooxygenase or 
lipoxygenase pathways in compounds with potent biological activities (Offenbacher, 1996). The cyclooxygenase enzymes are recognized to have two isoforms: cyclooxygenase 1 (COX1) which is a constitutive enzyme present in most of cells and cyclooxygenase 2 (COX2) which is inducible and is present in cells involved in inflammatory processes (DeWitt, et al., 1993). The cyclooxygenase pathway produces prostaglandins, prostacyclin and thromboxane, called prostanoids. Some prostanoids have proinflammatory properties and have been associated with destructive process in inflammatory diseases. In periodontal diseases, Prostaglandin $\mathrm{E}_{2}\left(\mathrm{PGE}_{2}\right)$ has been extensively correlated to inflammation and bone resorption (Offenbacher, 1996). Its levels in gingival tissues and in the gingival crevicular fluid (GCF) have been shown to be significantly elevated in periodontally diseased patients compared to healthy patients (Dewhirst, et al., 1983, Offenbacher, et al., 1981).

Selective NSAIDs are capable of inhibiting COX-2 without affecting constitutive isoform COX-1. Some studies have indicated that COX-2 inhibitors retain bone sparing effects (Bezerra, et al., 2000, Holzhausen, et al., 2002, Holzhausen, et al., 2005, Shimizu, et al., 1998) without inducing adverse effects associated with COX-1 suppression, such as gastroduodenal problems and renal toxicity (Hawkey, 1993, Lindsley and Warady, 1990). Several adjunctive periodontal clinical trials have been conducted with NSAIDs. In a systematic review (Reddy, et al., 2003), ten clinical studies in which therapeutic outcomes of NSAIDs were expressed in clinical attachment level (CAL) or alveolar crestal height as measured by subtraction radiography were selected. In these studies a variety of different NSAIDs were systemically or locally administered, including flurbiprofen, meclofenamate, ibuprofen, ketorolac, naproxen and aspirin. Although the heterogeneity of data did not permit a metaanalysis, limited quantitative analysis tended to show a significant benefit related to alveolar bone maintenance when NSAIDs were combined with conventional therapy. Notably, none of these studies found significantly less attachment loss after NSAIDs adjunctive therapy when compared to SRP alone.

\subsection{Anti-bone resorptive therapeutics}

Alveolar bone destruction is the hallmark feature of periodontal disease. The use of bonesparing drugs that inhibit alveolar bone resorption is another field in host-modulation therapy. Bisphosphonates are a class of agents that binds to hydoxyapatite in bone matrix to prevent matrix dissolution by interfering with osteoclast function through a variety of direct and indirect mechanisms (Rogers, et al., 2000). The principal therapeutic purpose of bisphosphonates is in the prevention and treatment of osteoporosis and also in treatment of Paget's disease and metastatic bone disease (Fleisch, 1997). In periodontics, their use was proposed initially for diagnostic and therapeutic use. As therapeutic agents, bisphosphonates were shown to reduce alveolar bone loss and increase mineral density but not to improve clinical conditions in animal periodontitis models (Brunsvold, et al., 1992, Reddy, et al., 1995). Five studies that assessed the effect of bisphosphonates as an adjunctive agent to SRP in human periodontal treatment were found to date (El-Shinnawi and ElTantawy, 2003, Jeffcoat, et al., 2007, Lane, et al., 2005, Rocha, et al., 2004, Rocha, et al., 2001). Alendronate was the bisphosphonate used in four studies during a period of 6 months. One study used risedronate during 12 months (El-Shinnawi and El-Tantawy, 2003). All the studies presented significant clinical improvement when compared to placebo, including: probing depth reduction, clinical attachement gain, bleeding on probing reduction, alveolar bone gain and increase in bone mineral density. These results encourage the use of 
bisphosphonates as an adjunctive agent to periodontal therapy. Additional studies need to be implemented to confirm the benefits of these drugs.

However, there can be significant dental related adverse effects associated with the use of bisphosphonates therapeutics. High-dose, long-term use of bisphosphonates has been reported to be associated with osteonecrosis of the jaw (ONJ) (Marx, 2003, Ruggiero, et al., 2004). Data from multiple sources indicates that patients with prior dental problems may have a higher risk of ONJ. However, as more data is being reported, it still remains controversial that bisphosphonates indeed are causative for ONJ. Since bisphosphonates are potent osteoclast inhibitors, their long-term use may suppress bone turnover and compromise healing of even physiologic micro-injuries within bone (Odvina, et al., 2005). Despite the encouraging therapeutic results, further long-term studies are warranted to determine the relative risk-benefit ratio of bisphosphonate therapy.

\section{Future host modulatory approaches}

A variety of treatment strategies have been developed to target the host response to LPSmediated tissue destruction. MMP inhibitors such as low dose formulations of doxycycline have been used in combination with scaling and root planing (Caton, et al., 2001) or surgical therapy (Gapski, et al., 2004). In addition, high-risk patient populations such as diabetics or patients with recurrent periodontal disease have benefited from systemic MMP administration (Chang, et al., 1996, Golub, et al., 2001, Novak, et al., 2002). Encouraging results have been shown using soluble antagonists of TNF and IL-1 delivered locally to periodontal tissues in nonhuman primates (Assuma, et al., 1998, Graves, et al., 1998).

\subsection{Novel host modulators}

Host response modulation is key therapeutic target used to control periodontal inflammation leading to tissue and bone destruction. Bone loss as a consequence of bacterial-induced inflammation due to subgingival plaque in the periodontal pocket is controlled by the expression of cytokines that direct the biological process of osteoclast differentiation. Several inflammatory cytokines, including interleukin (IL)-1, IL-6 and other cytokines enhance the expression of receptor activator of nuclear factor kappa-B ligand (RANKL) which induced osteoclast formation and leads to bone resorption. RANK is the receptor located on osteoclast precursor cells that respond to RANKL to initiate formation of mature osteoclasts. To balance the effects of RANKL, osteoprotegerin (OPG) acts as a decoy receptor to bind RANKL and inhibits osteoclast development. In periodontal disease, the roles of RANKL, RANK, and OPG in the alveolar bone resorption have been extensively investigated. Based on pre-clinical animal studies and on preliminary human clinical studies, the OPG/RANKL/RANK axis is a new target for the treatment of destructive periodontal disease and other bone resorption related diseases (Cochran, 2008). However, further studies are necessary to determine the most efficacious therapeutic approach based upon molecular interactions in the periodontal environment.

All immune cells within periodontal tissues generate innate immune cytokines require intracellular signaling to transduce extracellular cues into biochemical information required for inflammatory cytokine gene expression. Cytokines and bacterial components activate many signal transduction pathways. With this concept in mind, new strategies for preventing cell activation via targeting signal transduction pathways could abolish both cell 
activation by cytokines or other stimuli and production of proinflammatory cytokines. Signal transduction pathways closely involved in inflammation include the mitogenactivated protein kinase (MAPK) pathway, phosphatidylinositol-3 protein (PI3-kinase) pathway, janus kinase-signal transducer and activator of transcription (Jak-STAT), and nuclear factor kappa B (NF-kB). Thus, small molecule inhibitor compounds have emerged as the new therapeutic strategies that are being explored are aimed at inhibiting signal transduction pathways involved in inflammation. Pharmacological inhibitors of NF-kB and p38 mitogen activating protein (MAP) kinase pathways are actively being developed to manage inflammatory bone diseases (Adams, et al., 2001, Kumar, et al., 2001). p38 inhibitors have already shown promise in preclinical models of periodontal diseases (Kirkwood, et al., 2007, Rogers, et al., 2007). Using this novel strategy, inflammatory mediators including proinflammatory cytokines (IL-1, TNF, IL-6), MMPs and others would be inhibited the level of cell signaling pathways required for transcription factor activation necessary for inflammatory gene expression or mRNA stability. These therapies may provide the next wave of adjuvant chemotherapeutics that may be used to manage chronic periodontitis.

\section{Future directions}

Most therapeutics has relied on systemic delivery. Thus, it may be difficult to potentially use systemic therapeutics for periodontal disease due to the long-term chronic nature of the periodontal inflammation and destruction. The future may be the adjunctive use of locally delivered therapeutics, and the need for new targets of therapeutics for periodontal disease. Also, the need for new in situ delivery systems with the ability to locally deliver therapeutics to the periodontal lesion bypassing systemic issues of toxicity.

\section{Acknowledgment}

This work was supported by P20RR017696 and R01DE018290 from the National Institutes of Health.

\section{References}

Adams, J. L., A. M. Badger, S. Kumar, and J. C. Lee. 'P38 Map Kinase: Molecular Target for the Inhibition of Pro-Inflammatory Cytokines', Prog Med Chem Vol. 38, 1-60, 2001.

Addy, M. 'Oral Hygiene Products: Potential for Harm to Oral and Systemic Health?', Periodontol 2000 Vol. 48, No. 1, 54-65, 2008.

Ainamo, J., T. Lie, B. H. Ellingsen, B. F. Hansen, L. A. Johansson, T. Karring, J. Kisch, K. Paunio, and K. Stoltze. 'Clinical Responses to Subgingival Application of a Metronidazole 25\% Gel Compared to the Effect of Subgingival Scaling in Adult Periodontitis', J Clin Periodontol Vol. 19, No. 9 Pt 2, 723-9, 1992.

Assuma, R., T. Oates, D. Cochran, S. Amar, and D. T. Graves. 'Il-1 and Tnf Antagonists Inhibit the Inflammatory Response and Bone Loss in Experimental Periodontitis', J Immunol Vol. 160, No. 1, 403-9, 1998.

Baelum, V., and O. Fejerskov. 'Tooth Loss as Related to Dental Caries and Periodontal Breakdown in Adult Tanzanians', Community Dent Oral Epidemiol Vol. 14, No. 6, 353-7, 1986. 
Baelum, V., L. Wen-Min, O. Fejerskov, and C. Xia. 'Tooth Mortality and Periodontal Conditions in 60-80-Year-Old Chinese', Scand J Dent Res Vol. 96, No. 2, 99-107, 1988.

Bezerra, M. M., V. de Lima, V. B. Alencar, I. B. Vieira, G. A. Brito, R. A. Ribeiro, and F. A. Rocha. 'Selective Cyclooxygenase-2 Inhibition Prevents Alveolar Bone Loss in Experimental Periodontitis in Rats', J Periodontol Vol. 71, No. 6, 1009-14, 2000.

Birkedal-Hansen, H. 'Role of Cytokines and Inflammatory Mediators in Tissue Destruction', J Periodontal Res Vol. 28, No. 6 Pt 2, 500-10, 1993.

Bonito, A. J., L. Lux, and K. N. Lohr. 'Impact of Local Adjuncts to Scaling and Root Planing in Periodontal Disease Therapy: A Systematic Review', J Periodontol Vol. 76, No. 8, 1227-36, 2005.

Brunsvold, M. A., E. S. Chaves, K. S. Kornman, T. B. Aufdemorte, and R. Wood. 'Effects of a Bisphosphonate on Experimental Periodontitis in Monkeys', J Periodontol Vol. 63, No. 10, 825-30, 1992.

Burns, F. R., M. S. Stack, R. D. Gray, and C. A. Paterson. 'Inhibition of Purified Collagenase from Alkali-Burned Rabbit Corneas', Invest Ophthalmol Vis Sci Vol. 30, No. 7, 156975, 1989.

Caton, J. G., S. G. Ciancio, T. M. Blieden, M. Bradshaw, R. J. Crout, A. F. Hefti, J. M. Massaro, A. M. Polson, J. Thomas, and C. Walker. 'Subantimicrobial Dose Doxycycline as an Adjunct to Scaling and Root Planing: Post-Treatment Effects', J Clin Periodontol Vol. 28, No. 8, 782-9, 2001.

Chang, K. M., M. E. Ryan, L. M. Golub, N. S. Ramamurthy, and T. F. McNamara. 'Local and Systemic Factors in Periodontal Disease Increase Matrix-Degrading Enzyme Activities in Rat Gingiva: Effect of Micocycline Therapy', Res Commun Mol Pathol Pharmacol Vol. 91, No. 3, 303-18, 1996.

Ciancio, Sebastian. 'Non-Surgical Periodontal Treatment', Procedings of the World Workshop in Cinical Periodontics Vol. II, II1-II12, 1989.

Cionca, N., C. Giannopoulou, G. Ugolotti, and A. Mombelli. 'Amoxicillin and Metronidazole as an Adjunct to Full-Mouth Scaling and Root Planing of Chronic Periodontitis', J Periodontol Vol. 80, No. 3, 364-71, 2009.

Cochran, D. L. 'Inflammation and Bone Loss in Periodontal Disease', J Periodontol Vol. 79, No. 8 Suppl, 1569-76, 2008.

Dastoor, S. F., S. Travan, R. F. Neiva, L. A. Rayburn, W. V. Giannobile, and H. L. Wang. 'Effect of Adjunctive Systemic Azithromycin with Periodontal Surgery in the Treatment of Chronic Periodontitis in Smokers: A Pilot Study', J Periodontol Vol. 78, No. 10, 1887-96, 2007.

DePaola, L. G., C. D. Overholser, T. F. Meiller, G. E. Minah, and C. Niehaus. 'Chemotherapeutic Inhibition of Supragingival Dental Plaque and Gingivitis Development', J Clin Periodontol Vol. 16, No. 5, 311-5, 1989.

Dewhirst, F. E., D. E. Moss, S. Offenbacher, and J. M. Goodson. 'Levels of Prostaglandin E2, Thromboxane, and Prostacyclin in Periodontal Tissues', J Periodontal Res Vol. 18, No. 2, 156-63, 1983.

DeWitt, D. L., E. A. Meade, and W. L. Smith. 'Pgh Synthase Isoenzyme Selectivity: The Potential for Safer Nonsteroidal Antiinflammatory Drugs', Am J Med Vol. 95, No. 2A, 40S-44S, 1993. 
El-Shinnawi, U. M., and S. I. El-Tantawy. 'The Effect of Alendronate Sodium on Alveolar Bone Loss in Periodontitis (Clinical Trial)', J Int Acad Periodontol Vol. 5, No. 1, 5-10, 2003.

Ellen, R. P., and C. A. McCulloch. 'Evidence Versus Empiricism: Rational Use of Systemic Antimicrobial Agents for Treatment of Periodontitis', Periodontol 2000 Vol. 10, 2944, 1996.

Elter, J. R., H. P. Lawrence, S. Offenbacher, and J. D. Beck. 'Meta-Analysis of the Effect of Systemic Metronidazole as an Adjunct to Scaling and Root Planing for Adult Periodontitis', J Periodontal Res Vol. 32, No. 6, 487-96, 1997.

Feller, L., and J. Lemmer. 'Necrotizing Periodontal Diseases in Hiv-Seropositive Subjects: Pathogenic Mechanisms', J Int Acad Periodontol Vol. 10, No. 1, 10-5, 2008.

Fleisch, H. A. 'Bisphosphonates: Preclinical Aspects and Use in Osteoporosis', Ann Med Vol. 29, No. 1, 55-62, 1997.

Flotra, L., P. Gjermo, G. Rolla, and J. Waerhaug. 'A 4-Month Study on the Effect of Chlorhexidine Mouth Washes on 50 Soldiers', Scand J Dent Res Vol. 80, No. 1, 10-7, 1972.

Fornell, J., Y. Sundin, and J. Lindhe. 'Effect of Listerine on Dental Plaque and Gingivitis', Scand J Dent Res Vol. 83, No. 1, 18-25, 1975.

Gapski, R., J. L. Barr, D. P. Sarment, M. G. Layher, S. S. Socransky, and W. V. Giannobile. 'Effect of Systemic Matrix Metalloproteinase Inhibition on Periodontal Wound Repair: A Proof of Concept Trial', J Periodontol Vol. 75, No. 3, 441-52, 2004.

Garrett, S., L. Johnson, C. H. Drisko, D. F. Adams, C. Bandt, B. Beiswanger, G. Bogle, K. Donly, W. W. Hallmon, E. B. Hancock, P. Hanes, C. E. Hawley, R. Kiger, W. Killoy, J. T. Mellonig, A. Polson, F. J. Raab, M. Ryder, N. H. Stoller, H. L. Wang, L. E. Wolinsky, G. H. Evans, C. Q. Harrold, R. M. Arnold, G. L. Southard, and et al. 'Two Multi-Center Studies Evaluating Locally Delivered Doxycycline Hyclate, Placebo Control, Oral Hygiene, and Scaling and Root Planing in the Treatment of Periodontitis', J Periodontol Vol. 70, No. 5, 490-503, 1999.

Golub, L. M., S. Ciancio, N. S. Ramamamurthy, M. Leung, and T. F. McNamara. 'Low-Dose Doxycycline Therapy: Effect on Gingival and Crevicular Fluid Collagenase Activity in Humans', J Periodontal Res Vol. 25, No. 6, 321-30, 1990.

Golub, L. M., J. M. Goodson, H. M. Lee, A. M. Vidal, T. F. McNamara, and N. S. Ramamurthy. 'Tetracyclines Inhibit Tissue Collagenases. Effects of Ingested Low-Dose and Local Delivery Systems', J Periodontol Vol. 56, No. 11 Suppl, 93-7, 1985.

Golub, L. M., T. F. McNamara, M. E. Ryan, B. Kohut, T. Blieden, G. Payonk, T. Sipos, and H. J. Baron. 'Adjunctive Treatment with Subantimicrobial Doses of Doxycycline: Effects on Gingival Fluid Collagenase Activity and Attachment Loss in Adult Periodontitis', J Clin Periodontol Vol. 28, No. 2, 146-56, 2001.

Gomi, K., A. Yashima, T. Nagano, M. Kanazashi, N. Maeda, and T. Arai. 'Effects of FullMouth Scaling and Root Planing in Conjunction with Systemically Administered Azithromycin', J Periodontol Vol. 78, No. 3, 422-9, 2007.

Goodson, J. M. 'Antimicrobial Strategies for Treatment of Periodontal Diseases', Periodontol 2000 Vol. 5, 142-68, 1994. 
Goodson, J. M., M. A. Cugini, R. L. Kent, G. C. Armitage, C. M. Cobb, D. Fine, M. E. Fritz, E. Green, M. J. Imoberdorf, W. J. Killoy, and et al. 'Multicenter Evaluation of Tetracycline Fiber Therapy: Ii. Clinical Response', J Periodontal Res Vol. 26, No. 4, 371-9, 1991.

Goodson, J. M., J. C. Gunsolley, S. G. Grossi, P. S. Bland, J. Otomo-Corgel, F. Doherty, and J. Comiskey. 'Minocycline Hcl Microspheres Reduce Red-Complex Bacteria in Periodontal Disease Therapy', J Periodontol Vol. 78, No. 8, 1568-79, 2007.

Gordon, J. M., I. B. Lamster, and M. C. Seiger. 'Efficacy of Listerine Antiseptic in Inhibiting the Development of Plaque and Gingivitis', J Clin Periodontol Vol. 12, No. 8, 697-704, 1985.

Graves, D. T., A. J. Delima, R. Assuma, S. Amar, T. Oates, and D. Cochran. 'Interleukin-1 and Tumor Necrosis Factor Antagonists Inhibit the Progression of Inflammatory Cell Infiltration toward Alveolar Bone in Experimental Periodontitis', J Periodontol Vol. 69, No. 12, 1419-25, 1998.

Greenwell, H. 'Position Paper: Guidelines for Periodontal Therapy', J Periodontol Vol. 72, No. 11, 1624-8, 2001.

Gusberti, F. A., P. Sampathkumar, B. E. Siegrist, and N. P. Lang. 'Microbiological and Clinical Effects of Chlorhexidine Digluconate and Hydrogen Peroxide Mouthrinses on Developing Plaque and Gingivitis', J Clin Periodontol Vol. 15, No. 1, 60-7, 1988.

Hawkey, C. J. 'Gastroduodenal Problems Associated with Non-Steroidal, Anti-Inflammatory Drugs (Nsaids)', Scand J Gastroenterol Suppl Vol. 200, 94-5, 1993.

Herrera, D., B. Alonso, R. Leon, S. Roldan, and M. Sanz. 'Antimicrobial Therapy in Periodontitis: The Use of Systemic Antimicrobials against the Subgingival Biofilm', J Clin Periodontol Vol. 35, No. 8 Suppl, 45-66, 2008.

Holzhausen, M., C. Rossa Junior, E. Marcantonio Junior, P. O. Nassar, D. M. Spolidorio, and L. C. Spolidorio. 'Effect of Selective Cyclooxygenase-2 Inhibition on the Development of Ligature-Induced Periodontitis in Rats', J Periodontol Vol. 73, No. 9, 1030-6, 2002.

Holzhausen, M., D. M. Spolidorio, M. N. Muscara, J. Hebling, and L. C. Spolidorio. 'Protective Effects of Etoricoxib, a Selective Inhibitor of Cyclooxygenase-2, in Experimental Periodontitis in Rats', J Periodontal Res Vol. 40, No. 3, 208-11, 2005.

Jeffcoat, M. K., G. Cizza, W. J. Shih, R. Genco, and A. Lombardi. 'Efficacy of Bisphosphonates for the Control of Alveolar Bone Loss in Periodontitis', J Int Acad Periodontol Vol. 9, No. 3, 70-6, 2007.

Kim, Y. J., C. Rossa, Jr., and K. L. Kirkwood. 'Prostaglandin Production by Human Gingival Fibroblasts Inhibited by Triclosan in the Presence of Cetylpyridinium Chloride', J Periodontol Vol. 76, No. 10, 1735-42, 2005.

Kirkwood, K. L., J. A. Cirelli, J. E. Rogers, and W. V. Giannobile. 'Novel Host Response Therapeutic Approaches to Treat Periodontal Diseases', Periodontol 2000 Vol. 43, 294-315, 2007.

Knoll-Kohler, E. 'Metronidazole Dental Gel as an Alternative to Scaling and Root Planing in the Treatment of Localized Adult Periodontitis. Is Its Efficacy Proved?', Eur J Oral Sci Vol. 107, No. 6, 415-21, 1999.

Kumar, S., B. J. Votta, D. J. Rieman, A. M. Badger, M. Gowen, and J. C. Lee. 'Il-1- and TnfInduced Bone Resorption Is Mediated by P38 Mitogen Activated Protein Kinase', J Cell Physiol Vol. 187, No. 3, 294-303, 2001. 
Lane, N., G. C. Armitage, P. Loomer, S. Hsieh, S. Majumdar, H. Y. Wang, M. Jeffcoat, and T. Munoz. 'Bisphosphonate Therapy Improves the Outcome of Conventional Periodontal Treatment: Results of a 12-Month, Randomized, Placebo-Controlled Study', J Periodontol Vol. 76, No. 7, 1113-22, 2005.

Lindsley, C. B., and B. A. Warady. 'Nonsteroidal Antiinflammatory Drugs. Renal Toxicity. Review of Pediatric Issues', Clin Pediatr (Phila) Vol. 29, No. 1, 10-3, 1990.

Loe, H., A. Anerud, H. Boysen, and E. Morrison. 'Natural History of Periodontal Disease in Man. Rapid, Moderate and No Loss of Attachment in Sri Lankan Laborers 14 to 46 Years of Age', J Clin Periodontol Vol. 13, No. 5, 431-45, 1986.

Loe, H., and C. R. Schiott. 'The Effect of Mouthrinses and Topical Application of Chlorhexidine on the Development of Dental Plaque and Gingivitis in Man', J Periodontal Res Vol. 5, No. 2, 79-83, 1970.

Loesche, W. J., J. R. Giordano, P. Hujoel, J. Schwarcz, and B. A. Smith. 'Metronidazole in Periodontitis: Reduced Need for Surgery', J Clin Periodontol Vol. 19, No. 2, 103-12, 1992.

Loesche, W. J., S. A. Syed, E. C. Morrison, G. A. Kerry, T. Higgins, and J. Stoll. 'Metronidazole in Periodontitis. I. Clinical and Bacteriological Results after 15 to 30 Weeks', J Periodontol Vol. 55, No. 6, 325-35, 1984.

Lopez, N. J., J. A. Gamonal, and B. Martinez. 'Repeated Metronidazole and Amoxicillin Treatment of Periodontitis. A Follow-up Study', J Periodontol Vol. 71, No. 1, 79-89, 2000.

Machion, L., D. C. Andia, G. Lecio, F. H. Nociti, Jr., M. Z. Casati, A. W. Sallum, and E. A. Sallum. 'Locally Delivered Doxycycline as an Adjunctive Therapy to Scaling and Root Planing in the Treatment of Smokers: A 2-Year Follow-Up', J Periodontol Vol. 77, No. 4, 606-13, 2006.

Marx, R. E. 'Pamidronate (Aredia) and Zoledronate (Zometa) Induced Avascular Necrosis of the Jaws: A Growing Epidemic', J Oral Maxillofac Surg Vol. 61, No. 9, 1115-7, 2003.

Mealey, B. L. 'Impact of Advances in Diabetes Care on Dental Treatment of the Diabetic Patient', Compend Contin Educ Dent Vol. 19, No. 1, 41-4, 46-8, 50 passim; quiz 60, 1998.

Ng, V. W., and N. F. Bissada. 'Clinical Evaluation of Systemic Doxycycline and Ibuprofen Administration as an Adjunctive Treatment for Adult Periodontitis', J Periodontol Vol. 69, No. 7, 772-6, 1998.

Novak, M. J., L. P. Johns, R. C. Miller, and M. H. Bradshaw. 'Adjunctive Benefits of Subantimicrobial Dose Doxycycline in the Management of Severe, Generalized, Chronic Periodontitis', J Periodontol Vol. 73, No. 7, 762-9, 2002.

Odvina, C. V., J. E. Zerwekh, D. S. Rao, N. Maalouf, F. A. Gottschalk, and C. Y. Pak. 'Severely Suppressed Bone Turnover: A Potential Complication of Alendronate Therapy', J Clin Endocrinol Metab Vol. 90, No. 3, 1294-301, 2005.

Offenbacher, S. 'Periodontal Diseases: Pathogenesis', Ann Periodontol Vol. 1, No. 1, 821-78, 1996.

Offenbacher, S., D. H. Farr, and J. M. Goodson. 'Measurement of Prostaglandin E in Crevicular Fluid', J Clin Periodontol Vol. 8, No. 4, 359-67, 1981.

Overholser, C. D., T. F. Meiller, L. G. DePaola, G. E. Minah, and C. Niehaus. 'Comparative Effects of 2 Chemotherapeutic Mouthrinses on the Development of Supragingival Dental Plaque and Gingivitis', J Clin Periodontol Vol. 17, No. 8, 575-9, 1990. 
Pires, J.R., C.J. Rossa, and A.C. Pizzolitto. 'In Vitro Antimicrobial Efficiency of a Mouthwash Containing Triclosan/Gantrez and Sodium Bicarbonate', Braz Oral REs Vol. 21, No. 4, 342-7, 2007.

Pradeep, A. R., S. V. Sagar, and H. Daisy. 'Clinical and Microbiologic Effects of Subgingivally Delivered $0.5 \%$ Azithromycin in the Treatment of Chronic Periodontitis', J Periodontol Vol. 79, No. 11, 2125-35, 2008.

Reddy, M. S., N. C. Geurs, and J. C. Gunsolley. 'Periodontal Host Modulation with Antiproteinase, Anti-Inflammatory, and Bone-Sparing Agents. A Systematic Review', Ann Periodontol Vol. 8, No. 1, 12-37, 2003.

Reddy, M. S., T. W. Weatherford, 3rd, C. A. Smith, B. D. West, M. K. Jeffcoat, and T. M. Jacks. 'Alendronate Treatment of Naturally-Occurring Periodontitis in Beagle Dogs', J Periodontol Vol. 66, No. 3, 211-7, 1995.

Rocha, M. L., J. M. Malacara, F. J. Sanchez-Marin, C. J. Vazquez de la Torre, and M. E. Fajardo. 'Effect of Alendronate on Periodontal Disease in Postmenopausal Women: A Randomized Placebo-Controlled Trial', J Periodontol Vol. 75, No. 12, 1579-85, 2004.

Rocha, M., L. E. Nava, C. Vazquez de la Torre, F. Sanchez-Marin, M. E. Garay-Sevilla, and J. M. Malacara. 'Clinical and Radiological Improvement of Periodontal Disease in Patients with Type 2 Diabetes Mellitus Treated with Alendronate: A Randomized, Placebo-Controlled Trial', J Periodontol Vol. 72, No. 2, 204-9, 2001.

Rogers, J. E., F. Li, D. D. Coatney, J. Otremba, J. M. Kriegl, T. A. Protter, L. S. Higgins, S. Medicherla, and K. L. Kirkwood. 'A P38 Mitogen-Activated Protein Kinase Inhibitor Arrests Active Alveolar Bone Loss in a Rat Periodontitis Model', J Periodontol Vol. 78, No. 10, 1992-8, 2007.

Rogers, M. J., S. Gordon, H. L. Benford, F. P. Coxon, S. P. Luckman, J. Monkkonen, and J. C. Frith. 'Cellular and Molecular Mechanisms of Action of Bisphosphonates', Cancer Vol. 88, No. 12 Suppl, 2961-78, 2000.

Ruggiero, S. L., B. Mehrotra, T. J. Rosenberg, and S. L. Engroff. 'Osteonecrosis of the Jaws Associated with the Use of Bisphosphonates: A Review of 63 Cases', J Oral Maxillofac Surg Vol. 62, No. 5, 527-34, 2004.

Shimizu, N., Y. Ozawa, M. Yamaguchi, T. Goseki, K. Ohzeki, and Y. Abiko. 'Induction of Cox-2 Expression by Mechanical Tension Force in Human Periodontal Ligament Cells', J Periodontol Vol. 69, No. 6, 670-7, 1998.

Siegrist, BE., FA. Gusberti, MC Brecx, Weber HP, and NP Lang. 'Efficacy of Supervised Rinsing with Chlorhexidine Digluconate in Comparison to Phenolic and Plant Alkaloid Compounds', J Periodontal Res Vol. 21 (suppl. 16), No. 60, 1986.

Sigusch, B., M. Beier, G. Klinger, W. Pfister, and E. Glockmann. 'A 2-Step Non-Surgical Procedure and Systemic Antibiotics in the Treatment of Rapidly Progressive Periodontitis', J Periodontol Vol. 72, No. 3, 275-83, 2001.

Slots, J., and M. Ting. 'Systemic Antibiotics in the Treatment of Periodontal Disease', Periodontol 2000 Vol. 28, 106-76, 2002.

Socransky, S. S., and A. D. Haffajee. 'Evidence of Bacterial Etiology: A Historical Perspective', Periodontol 2000 Vol. 5, 7-25, 1994.

van Winkelhoff, A. J., T. E. Rams, and J. Slots. 'Systemic Antibiotic Therapy in Periodontics', Periodontol 2000 Vol. 10, 45-78, 1996. 
Watts, T., R. Palmer, and P. Floyd. 'Metronidazole: A Double-Blind Trial in Untreated Human Periodontal Disease', J Clin Periodontol Vol. 13, No. 10, 939-43, 1986.

Wennstrom, J. L., H. N. Newman, S. R. MacNeill, W. J. Killoy, G. S. Griffiths, D. G. Gillam, L. Krok, I. G. Needleman, G. Weiss, and S. Garrett. 'Utilisation of Locally Delivered Doxycycline in Non-Surgical Treatment of Chronic Periodontitis. A Comparative Multi-Centre Trial of 2 Treatment Approaches', J Clin Periodontol Vol. 28, No. 8, 75361, 2001.

Williams, R. C., D. W. Paquette, S. Offenbacher, D. F. Adams, G. C. Armitage, K. Bray, J. Caton, D. L. Cochran, C. H. Drisko, J. P. Fiorellini, W. V. Giannobile, S. Grossi, D. M. Guerrero, G. K. Johnson, I. B. Lamster, I. Magnusson, R. J. Oringer, G. R. Persson, T. E. Van Dyke, L. F. Wolff, E. A. Santucci, B. E. Rodda, and J. Lessem. 'Treatment of Periodontitis by Local Administration of Minocycline Microspheres: A Controlled Trial', J Periodontol Vol. 72, No. 11, 1535-44, 2001.

Winkel, E. G., A. J. Van Winkelhoff, M. F. Timmerman, U. Van der Velden, and G. A. Van der Weijden. 'Amoxicillin Plus Metronidazole in the Treatment of Adult Periodontitis Patients. A Double-Blind Placebo-Controlled Study', J Clin Periodontol Vol. 28, No. 4, 296-305, 2001. 


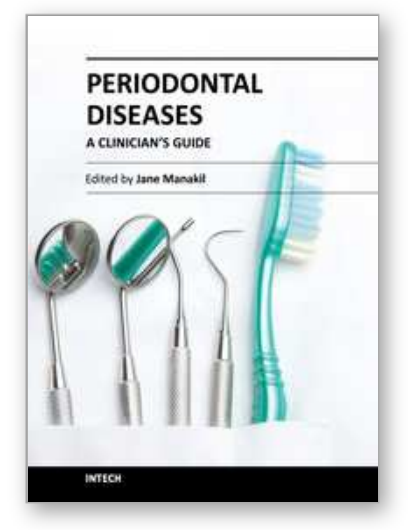

\author{
Periodontal Diseases - A Clinician's Guide \\ Edited by Dr. Jane Manakil
}

ISBN 978-953-307-818-2

Hard cover, 368 pages

Publisher InTech

Published online 03, February, 2012

Published in print edition February, 2012

"Periodontal diseases" is a web-based resource intended to reach the contemporary practitioners as well as educators and students in the field of periodontology. It is fully searchable and designed to enhance the learning experience. Within the book a description is presented of the current concepts presenting the complex interactions of microbial fingerprint, multiple genotypes, and host modulations. In addition, an overview is given of the clinical outcome of the disease's progression, as influenced by the epigenetic factors. Emerging concepts on periodontitis as a risk factor for various systemic diseases and as a bilateral modulating factor have been elucidated in detail as well.

\title{
How to reference
}

In order to correctly reference this scholarly work, feel free to copy and paste the following:

Renata S. Leite and Keith L. Kirkwood (2012). Present and Future Non-Surgical Therapeutic Strategies for the Management of Periodontal Diseases, Periodontal Diseases - A Clinician's Guide, Dr. Jane Manakil (Ed.), ISBN: 978-953-307-818-2, InTech, Available from: http://www.intechopen.com/books/periodontal-diseases-aclinician-s-guide/present-and-future-non-surgical-therapeutic-strategies-for-the-management-of-periodontaldiseases

\section{INTECH}

open science | open minds

\section{InTech Europe}

University Campus STeP Ri

Slavka Krautzeka 83/A

51000 Rijeka, Croatia

Phone: +385 (51) 770447

Fax: +385 (51) 686166

www.intechopen.com

\section{InTech China}

Unit 405, Office Block, Hotel Equatorial Shanghai

No.65, Yan An Road (West), Shanghai, 200040, China

中国上海市延安西路65号上海国际贵都大饭店办公楼405单元

Phone: +86-21-62489820

Fax: $+86-21-62489821$ 
(C) 2012 The Author(s). Licensee IntechOpen. This is an open access article distributed under the terms of the Creative Commons Attribution 3.0 License, which permits unrestricted use, distribution, and reproduction in any medium, provided the original work is properly cited. 